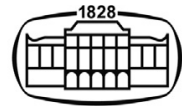

AKADÉMIAI KIADÓ

Acta Veterinaria

Hungarica

68 (2020) 1, 34-36

DOI:

10.1556/004.2020.00009

(c) 2020 Akadémiai Kiadó, Budapest

ORIGINAL ARTICLE

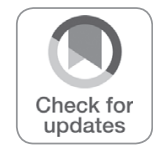

*Corresponding author.

Tel.: +7 9201495548.

E-mail: darya.a.morozova@gmail.com

\section{Common dace (Leuciscus leuciscus) - A new host of the myxozoan fish parasite, Myxobolus elegans (Cnidaria: Myxozoa) - Short communication}

\author{
DARIA A. MOROZOVA ${ }^{1 *}$ (D), VLADIMIR N. VORONIN ${ }^{2}$ and \\ ALEXEY V. KATOKHIN ${ }^{3}$
}

\author{
${ }^{1}$ Papanin Institute for Biology of Inland Waters, Russian Academy of Sciences, Yaroslavskaya oblast \\ 109, Borok, 152742, Russia \\ ${ }^{2}$ Federal State Budgetary Educational Institution of Higher Education, St. Petersburg State Academy \\ of Veterinary Medicine, Saint Petersburg, Russia \\ ${ }^{3}$ Institute of Cytology and Genetics, Siberian Branch of Russian Academy of Sciences, Novosibirsk, \\ Russia
}

Received: April 19, 2019 • Accepted: November 14, 2019

Published online: May 8, 2020

\begin{abstract}
This paper reports the detection of the myxozoan species Myxobolus elegans Kashkovsky 1966 in common dace (Leuciscus leuciscus) that has not been previously listed as its host. The problem of differentiation of phenotypically similar Myxobolus species is addressed. During parasitological survey of common dace from the desalinated part of the Gulf of Finland at the city of Sestroretsk, Russia, numerous oval-shaped plasmodia, $0.2-0.4 \mathrm{~mm}$ in size, filled with Myxobolus spores were found on the gills. Pear-shaped myxospores were $15.4(14.8-16.0) \times 10.2(9.6-10.9) \mu \mathrm{m}$ in size with a rib on each valve. On the basis of spore morphology, the species appeared to be similar to M. elegans and Myxobolus hungaricus Jaczó, 1940. In order to identify the species, molecular genetic analysis was performed, and the species was identified on the basis of morphological characteristics and 18S rDNA data. The results obtained indicate that the Myxobolus species observed on the gills of dace is M. elegans. Thus, common dace is another valid host of M. elegans besides the type host, ide (Leuciscus idus).
\end{abstract}

\section{KEYWORDS}

Myxobolus elegans, Leuciscus leuciscus, Baltic Sea, morphotype, 18S rDNA

Members of the genus Myxobolus (Cnidaria: Myxozoa) are among the most widespread endoparasites of fish. Over 800 valid species of this genus are known, and the number of new species is increasing constantly (Eiras et al., 2005, 2014). The differentiation of Myxobolus species is based on spore morphology, host specificity and tissue tropism. Due to the high degree of morphological similarity, species identification is completed by the use of molecular methods - revealing differences in nucleotide sequences such as 18S rRNA genes (Molnár, 1994; Eszterbauer, 2002, 2004; Kallert et al., 2005; Molnár et al., 2010; Borzák et al., 2018; Sokolov and Lebedeva, 2018). We performed an ichthyoparasitological study of common dace (Leuciscus leuciscus) caught in the freshened part of the Gulf of Finland near the city of Sestroretsk $\left(60^{\circ} 05^{\prime} 11.7^{\prime \prime} \mathrm{N} 29^{\circ} 55^{\prime} 31.9^{\prime \prime} \mathrm{E}\right)$ in April 2015. On the gills of one fish specimen, multiple oval plasmodia $0.2-0.4 \mathrm{~mm}$ in size, containing spores of Myxobolus-like shape, were found. Temporary and glycerol-gelatin preparations for microscopy were made from the detected myxospores. Plasmodia were fixed in $96 \%$ ethanol for subsequent molecular analysis. Genomic DNA (gDNA) was extracted using a 100x DNA extraction kit (Biosilika LLC, Russia) following the manufacturer's manual.

Nested PCR assay was used to amplify the $18 \mathrm{~S}$ rDNA of the parasite, with the pair of universal primers $18 \mathrm{e}\left(5^{\prime}\right.$ CTG GTT GAT TCT GCC AGT $3^{\prime}$ ) and 18g (5' CGG TAC TAG CGA CGG GCG GTG TG 3' (Hillis and Dixon, 1991) in the first PCR round, and the primer pair of Myx1F (5' GTG AGA CTG CGG ACG GCT CAG $3^{\prime}$ ) and Myx4R 
(5' CTG ACA GAT CAC TCC ACG AAC $3^{\prime}$ ) in the second round (Hallett and Diamant, 2001).

The PCR reaction mixture of $20 \mu \mathrm{L}$ volume contained (final concentrations are given): $1 \times$ Taq buffer (SibEnzyme Ltd, Russia), $1.5 \mathrm{mM} \mathrm{MgCl}, 250 \mu \mathrm{M}$ of each deoxyribonucleotide, $200 \mathrm{nM}$ of forward and reverse primers, 1 unit of Taq DNA-polymerase (SibEnzyme Ltd, Russia) and $100 \mathrm{ng}$ of genomic DNA. The amplification program consisted of the following stages: DNA denaturation at $94{ }^{\circ} \mathrm{C}$ for $2 \mathrm{~min}, 36$ cycles including denaturation at $94{ }^{\circ} \mathrm{C}$ for $30 \mathrm{sec}$, primer annealing at $54{ }^{\circ} \mathrm{C}$ for $20 \mathrm{sec}$ and elongation at $72{ }^{\circ} \mathrm{C}$ for $30 \mathrm{sec}$.

Agarose gel electrophoresis was performed in $1 \%$ agarose gel containing $0.1 \%$ ethidium bromide in Tris-acetate buffer. Before DNA sequencing, the PCR products were purified on spin columns using Sephadex G-50 Superfine sorbent (GE Healthcare, USA).

Sanger sequencing was performed using Big Dye terminator cycle sequencing kit v.3.1 (Applied Biosystems, Thermo Fisher Scientific, USA) using the primers $18 \mathrm{e}, 18 \mathrm{~g}$, Myx1F and Myx4R. Sanger reaction products were analysed using ABI 3130XL Genetic Analyzer (Applied Biosystems, Thermo Fisher Scientific, USA).

Nucleotide sequence polymorphism was analysed using MEGA6 software (Tamura et al., 2013). The degree of nucleotide sequence differences was evaluated by calculating the p-distance; a JC model of nucleotide substitutes selected during the model testing was used (Jukes and Cantor, 1969). The partial 18S rDNA sequence was deposited to GenBank (NCBI) under the accession number MH069207.

The myxospores found were pyriform, 15.4 (14.8-16.0) $\times 10.2(9.6-10.9) \mu \mathrm{m}$ in size (Fig. 1), and detailed inspection showed that each valve possessed a ridge (Fig. 1, inset). On the basis of spore morphology the species at hand was identified as Myxobolus elegans Kashkovsky 1966.

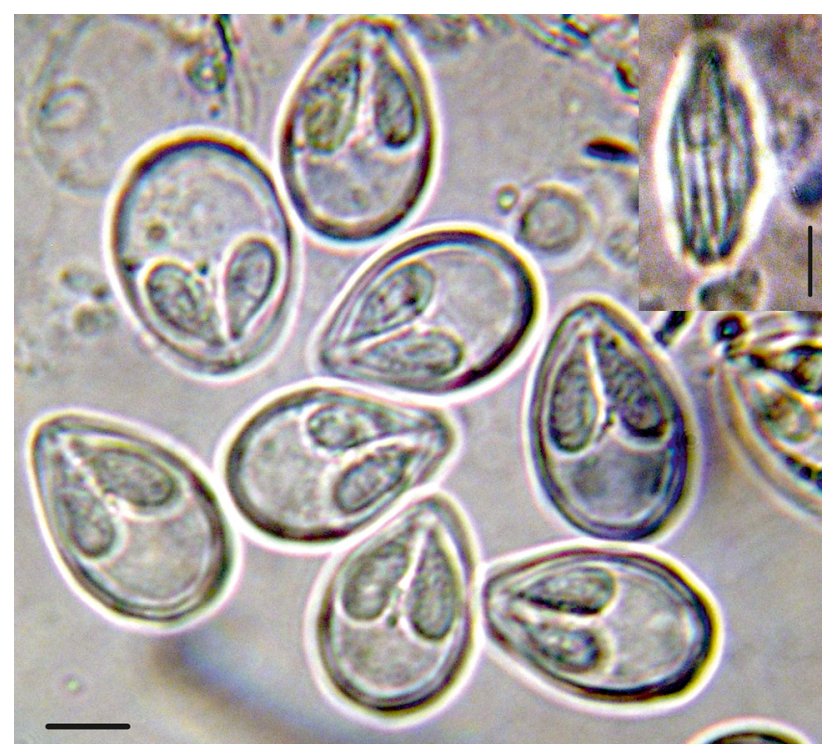

Figure 1. Myxospores of Myxobolus elegans from common dace (Leuciscus leuciscus), in frontal view. Native preparation. Scale bar: $5 \mu \mathrm{m}$. Inset: myxospore in side view. Scale bar: $5 \mu \mathrm{m}$
According to the original description (by Kashkovsky, referred in Shulman, 1966), M. elegans was found on the gill arches, gills and fins of two fish species: ide, Leuciscus idus (26.2\% occurrence) and roach, Rutilus rutilus (1.7\% occurrence) from the Iriklinskoe Reservoir (the Ural River) and the Chusovaya River (the Volga River basin). They found that ide was the most intensively infested species, with an average of 14 plasmodia per fish. The plasmodia of M. elegans were rounded or oval in shape, $0.17-0.34 \mathrm{~mm}$ long by $0.23-0.55 \mathrm{~mm}$ wide, and encircled by a thin connective tissue envelope. The myxospores were ovoid in shape, narrowing towards the anterior end. The sutural edge was slightly protruded above the spore surface. Each valve possessed one ridge located near the sutural edge, almost parallel to it. The myxospores were $13.5-17 \mu \mathrm{m}$ long, 7.4-10 $\mu \mathrm{m}$ wide and $7.4-8$ thick. Polar capsules were pyriform and uniform in size. They were $6.8-8 \mu \mathrm{m}$ long and $2.5-3.5 \mu \mathrm{m}$ wide. The shape and morphometrics of $M$. elegans detected in the present study were similar to those in the original description.

The spore morphology of $M$. elegans is similar to that of Myxobolus hungaricus Jaczó, 1940. Re-description of $M$. hungaricus found in common bream Abramis brama (Hungary, Lake Balaton and the River Danube) showed that mature plasmodia were rounded or elliptical in shape, reaching 0.35-0.45 $\times 0.17-0.35 \mathrm{~mm}$ in size (Baska and Molnár, 1999). The myxospores were symmetric with a distinct ridge parallel to the valve, averaging $11.9 \times 7.0 \mu \mathrm{m}$. The polar capsules were similar in size and shape. Differentiation of M. hungaricus and M. elegans spores was found to be difficult as they were morphologically similar although slightly different in size (Baska and Molnár, 1999). Currently, the identification of morphologically indistinguishable Myxobolus species is based on the 18S rDNA (Molnár et al., 2010; Cech et al., 2012). The two Myxobolus species, M. hungaricus and M. elegans, could be easily distinguished using the PCR-related restriction fragment length polymorphism (RFLP) technique (Eszterbauer et al., 2001; Eszterbauer, 2002).

We have performed DNA sequencing of the myxozoan found in common dace in order to confirm the identification of $M$. elegans. A 522-bp-long 18S rDNA fragment of $M$. elegans was analysed. The sequenced fragment was located in the region between nucleotide positions 40 and 561 of $M$. elegans sequences available in GenBank (AF448445, JN252485). BLAST search revealed the highest similarity to M. elegans sequences (99.43-99.81\%). When comparing the obtained $M$. elegans DNA sequence with the ones in GenBank (AF448445, JN252485), the p-distance varies from 0.2 to $0.6 \%$. Comparison of the obtained $M$. elegans DNA sequence to the $18 \mathrm{~S}$ rDNA of $M$. hungaricus (AF448444) showed a p-distance of $60.9 \%$. The p-distance between $M$. elegans (AF448445) and M. hungaricus (AF448444) was $61.3 \%$, while that between the studied M. elegans (JN252485) and M. hungaricus (AF448444) was $61.7 \%$.

Therefore, the obtained results proved that the myxozoan found in common dace was indeed $M$. elegans. Furthermore, we confirmed that common dace is another 
valid host of $M$. elegans besides the type host, ide. According to Shulman (1966), M. elegans has been found in the following hosts: roach (Rutilus rutilus), ide (Leuciscus idus), common bream (Abramis brama), sichel (Pelecus cultratus), asp (Leuciscus aspius) and lake minnow (Rhynchocypris percnurus) (Bauer, 1984). Ide and common dace represent the same genus, while all other fish belong to other cyprinid genera. It is possible that common bream caught in Russia was in fact infested with M. hungaricus, and the parasite was misidentified as $M$. elegans. Thus, we assume that the host range of $M$. elegans described so far might contain invalid hosts, and additional studies are required for clarification.

\section{ACKNOWLEDGEMENTS}

The authors are grateful to Elena A. Borovikova for valuable comments and discussion. This research was performed in the framework of the state assignment of the Ministry of Education and Science of the Russian Federation (Theme No. AAAA-A18-118012690100-5).

\section{REFERENCES}

Baska, F. and Molnár, K. (1999): Redescription of Myxobolus hungaricus Jaczó, 1940 (Myxosporea: Myxobolidae), a parasite of bream (Abramis brama L.). Acta Vet. Hung. 47, 341-349.

Bauer, O. N. (1984): Identification Key of Parasites of the USSR Freshwater Fishes Fauna [in Russian]. Nauka, Leningrad. p. 428.

Borzák, R., Molnár, K., Cech, G. and Székely, C. (2018): Myxobolus infection in the cornea of the roach (Rutilus rutilus) in Lake Balaton. Acta Vet. Hung. 66, 250-257.

Cech, G., Molnár, K. and Székely, C. (2012): Molecular genetic studies on morphologically indistinguishable Myxobolus spp. infecting cyprinid fishes, with the description of three new species, M. alvarezae sp. nov., M. sitjae sp. nov. and M. eirasianus sp. nov. Acta Parasitol. 57, 354-366.

Eiras, J. C., Molnár, K. and Lu, Y. S. (2005): Synopsis of the species of Myxobolus Bütschli, 1882 (Myxozoa: Myxosporea: Myxobolidae). Syst. Parasitol. 61, 1-46.

Eiras, J. C., Zhang, J. and Molnár, K. (2014): Synopsis of the species of Myxobolus Bütschli, 1882 (Myxozoa: Myxosporea, Myxobolidae) described between 2005 and 2013. Syst. Parasitol. 88, 11-36.
Eszterbauer, E. (2002): Molecular biology can differentiate morphologically indistinguishable myxosporean species: Myxobolus elegans and M. hungaricus. Acta Vet. Hung. 50, 51-57.

Eszterbauer, E. (2004): Genetic relationship among gill-infecting Myxobolus species (Myxosporea) of cyprinids: molecular evidence of importance of tissue-specificity. Dis. Aquat. Organ. 58, $35-40$.

Eszterbauer, E., Benkő, M., Dán, Á. and Molnár, K. (2001): Identification of fish-parasitic Myxobolus (Myxosporea) species using a combined PCR-RFLP method. Dis. Aquat. Organ. 44, 3539.

Hallett, S. L. and Diamant, A. (2001): Ultrastructure and smallsubunit ribosomal DNA sequence of Henneguya lesteri n. sp. (Myxosporea), a parasite of sand whiting Sillago analis (Sillaginidae) from the coast of Queensland, Australia. Dis. Aquat. Organ. 46, 197-212.

Hillis, D. M. and Dixon, M. T. (1991): Ribosomal DNA: molecular evolution and phylogenetic inference. Q. Rev. Biol. 66, 411453.

Jukes, T. H. and Cantor, C. R. (1969): Evolution of protein molecules: mammalian protein metabolism. In: Munro, H. N. (ed.) Mammalian Protein Metabolism. Academic Press, New York. pp. 21-132.

Kallert, D. M., Eszterbauer, E., Erséus, C., El-Matbouli, M. and Haas, W. (2005): Life cycle studies of Myxobolus parviformis sp. n. (Myxozoa: Myxobolidae) from bream. Dis. Aquat. Organ. 66, 233-243.

Molnár, K. (1994): Comments on the host, organ and tissue specificity of fish myxosporeans and on the types of their intrapiscine development. Parasit. Hung. 27, 5-20.

Molnár, K., Marton, S., Székely, C. and Eszterbauer, E. (2010): Differentiation of Myxobolus spp. (Myxozoa: Myxobolidae) infecting roach (Rutilus rutilus) in Hungary. Parasitol. Res. 107, 1137-1150.

Sokolov, S. and Lebedeva, D. (2018): Myxidium shedkoae Sokolov, 2013 (Myxozoa: Myxidiidae), a parasite of the gallbladder of Perccottus glenii Dybowski, 1877 (Actinoptrygii: Odontobutidae): supplementary data on morphology and phylogenetic position based on 18s rDNA sequence analysis. Acta Vet. Hung. 66, 258-268.

Shulman, S. (1966): Myxosporean Fauna of the USSR. Nauka, Leningrad. p. 507.

Tamura, K., Stecher, G., Peterson, D., Filipski, A. and Kumar, S. (2013): MEGA6: Molecular Evolutionary Genetics Analysis version 6.0. Mol. Biol. Evol. 30, 2725-2729. 